\title{
Mitochondrial protein and HSP70 signaling after ischemia in hypothermic-adapted hearts augmented with glucose
}

\author{
XUE-HAN NING, CHENG-SU XU, AND MICHAEL A. PORTMAN \\ Cardiology Division, Department of Pediatrics, University of Washington, Seattle 98195; \\ and Children's Hospital and Regional Medical Center, Seattle, Washington 98105
}

\begin{abstract}
Ning, Xue-Han, Cheng-Su Xu, and Michael A. Portman. Mitochondrial protein and HSP 70 signaling after ischemia in hypothermic-adapted hearts augmented with glucose. Am. J. Physiol. 277 (Regulatory Integrative Comp. Physiol. 46): R11-R17, 1999.-Hypothermia improves resistance to subsequent ischemia in the cardioplegic-arrested heart (CAH). This adaptive process produces mRNA el evation for heat shock protein (HSP) 70-1 and mitochondrial proteins, adenine nucleotide translocator $\left(A N T_{1}\right)$, and $\beta-F_{1-}$ ATPase. Glucose in cardioplegia also enhances myocardial protection. These processes might be linked to reduced ATP depletion. To assess for synergism between these protective processes, isolated rabbit hearts $(n=91)$ were perfused at $37^{\circ} \mathrm{C}$ and exposed to ischemic cardioplegic arrest for $2 \mathrm{~h}$. Hearts were in four groups: control (C), hypothermia adapted (H) perfused to $31^{\circ} \mathrm{C} 20 \mathrm{~min}$ before ischemia, $22 \mathrm{mM}$ glucose (G) in cardioplegia, and hypothermic adaptation and glucose (HG). Developed pressure (DP), $\mathrm{dP} / \mathrm{dt}_{\max }$, and pressure rate product (PRP) improved ( $P<0.05)$ in $G, H$, and $H G$ compared with $C$ during reperfusion. DP and $P R P$ were elevated in $H G$ over $\mathrm{H}$ and $\mathrm{G}$. ATP was higher in $\mathrm{G}, \mathrm{H}$, and $\mathrm{HG}$, although no additional increase in $\mathrm{HG}$ over $\mathrm{H}$ was found. Lactate and $\mathrm{CO}_{2}$ production were elevated in $\mathrm{G}$ only. The mRNA expression for HSP 70- 1, ANT 1 , and $\beta-\mathrm{F}_{1}$-ATPase was el evated severalfold in $H$ and $H G$, but not $G$ over $C$ during reperfusion. In conclusion, glucose provides additional functional improvement in $\mathrm{H}$. Additionally, neither ATP levels nor anaerobic metabolism are linked to mRNA expression for $\mathrm{HSP} 70, \mathrm{ANT}_{1}$, or $\beta-\mathrm{F}_{1}$-ATPase in $\mathrm{CAH}$.
\end{abstract}

stress response; RNA; cardiac surgery

METABOLIC ALTERATIONS, resulting from a brief hypothermic exposure, improve resistance to subsequent ischemic and reperfusion injury at warmer temperatures. Decreased ATP depletion during ischemia represents a prominent feature of hypothermic adaptation. This results from a hypothermia-induced reduction in ATP use, which persists during subsequent warm ischemia (10). Characteristics of this adaptive process include enhanced postischemic gene expression for specific stress-related proteins and constitutive mitochondrial membrane proteins (10). The response of these transcript levels emulates expression induced by cold stress in cold-adapted tissues from hibernating species (5). Preservation of ATP appears to be closely linked to improved postischemic function after cardioplegic arrest and reperfusion after hypothermic adaptation in the isolated rabbit heart model (10). However, it re-

The costs of publication of this article were defrayed in part by the payment of page charges. The article must therefore be hereby marked "advertisement" in accordance with 18 U.S.C. Section 1734 solely to indicate this fact. mains unclear whether a causative relationship exists between ATP maintenance and enhancement of the heat shock protein (HSP) response or preservation of signaling for mitochondrial biogenesis.

Other metabolic strategies can also improve ATP preservation during cardioplegic arrest and ischemia in an isolated perfused heart. Specifically, glucose, provided in the cardioplegia, promotes anaerobic ATP synthesis and limits ischemic ATP depletion (9). In this study, we propose two hypotheses. First, glucose in cardioplegia further augments myocardial protection and ATP preservation after hypothermic adaptation. Second, we propose that lactate and/or ATP levels are directly linked to gene expression for heat shock and mitochondrial membrane proteins, and the postulated metabolic augmentation should elevate these transcript levels. Alternatively, finding no observablechange in gene expression would imply that signal preservation induced by hypothermic adaptation is not caused by changes in energy metabolism and ATP availability. Studies were performed in a perfused rabbit heart model, which has previously demonstrated the propensity for hypothermic adaptation. Similar to previous work, cardiac function and ATP preservation were measured to index resistance to ischemia (10). Northern blot analyses were used to assess expression for inducible HSP 70- 1 and the genes regulating the mitochondrial membrane proteins [adeninenucl eotide translocator isoform $1\left(\mathrm{ANT}_{1}\right)$ and $\beta$-subunit $\mathrm{F}_{1}$-ATPase $\left(\beta-\mathrm{F}_{1}-\mathrm{ATP}\right.$ ase $)$.

\section{METHODS}

Preparation of isolated heart. Rabbits (male or female, $2.2-2.7 \mathrm{~kg}$ body wt) were anesthetized with pentobarbital sodium ( $45 \mathrm{mg} / \mathrm{kg} \mathrm{iv}$ ) and heparinized (700 U/kg iv). The heart was rapidly excised and immersed momentarily in ice-cold physiological salt solution (PSS), $\mathrm{pH} 7.4$, containing (in $\mathrm{mmol} / \mathrm{l}) 118.0 \mathrm{~N} \mathrm{aCl}, 4.0 \mathrm{~K} \mathrm{Cl}, 22.3 \mathrm{NaHCO}_{3}, 11.1$ glucose, 0.66 $\mathrm{KH}_{2} \mathrm{PO}_{4}, 1.23 \mathrm{MgCl}_{2}$, and $2.38 \mathrm{CaCl}_{2}$. The aorta was cannulated in the Langendorff mode, and the heart was perfused with PSS that had been equilibrated with $95 \% \mathrm{O}_{2}-5 \% \mathrm{CO}_{2}$ at $37^{\circ} \mathrm{C}$ and passed twice through filters with 3.0- $\mu \mathrm{m}$ pore size. Perfusion pressure was maintained at $90 \mathrm{mmHg}$. An incision was made in the left atrium, and a fluid-filled latex balloon was passed through the mitral orifice and placed in the left ventricle. The balloon was connected to a pressure transducer for continuous measurement of left ventricular pressure (LVP) and its first derivative with respect to time (dP/dt). The caudal vena cavum, the left and right cranial vena cava, and the azygous vein were ligated. The pulmonary artery was cannulated to enable collection of coronary flow that was measured with a flowmeter (T201, Transonic Systems, I thaca, NY).

Theanal og signals were continuously recorded on a pressurized ink chart recorder (Gould, Cleveland, $\mathrm{OH}$ ) and an online 
computer (Macintosh, Biopac Analog Signal Acquisition System). To characterize cardiac function, developed pressure (DP) is defined as peak systolic pressure minus end-diastolic pressure (EDP). The product of heart rate (HR) and DP (PRP, $\mathrm{mmH} / \mathrm{min}$ ) was calculated to provide an estimate of myocardial work. Myocardial oxygen consumption $\left(\mathrm{MVO}_{2}\right)$ was calculated as $\mathrm{MVO}_{2}=\mathrm{CF} \times\left[\left(\mathrm{Pa}_{\mathrm{O}_{2}}-\mathrm{Pv}_{\mathrm{O}_{2}}\right) \times(\mathrm{c} / 760)\right]$, where $\mathrm{CF}$ is coronary flow $\left(\mathrm{ml} \cdot \mathrm{min}^{-1} \cdot \mathrm{g}\right.$ wet tissue $\left.{ }^{-1}\right), \mathrm{Pa}_{\mathrm{O}_{2}}-\mathrm{Pv}_{\mathrm{O}_{2}}$ is the difference in the partial pressure of oxygen $\left(\mathrm{PO}_{2}, \mathrm{mmHg}\right)$ between perfusate and coronary effluent, and $c$ is the Bunsen solubility coefficient of $\mathrm{O}_{2}$ in perfusate at $37^{\circ} \mathrm{C}(22.7 \mu \mathrm{l}$ $\mathrm{O}_{2} \cdot$ atm $^{-1} \cdot \mathrm{ml}$ perfusate ${ }^{-1}$ ) (9-12). Oxygen extraction was calculated as $\mathrm{O}_{2} \mathrm{Ext}=\mathrm{MVO}_{2} /$ oxygen content in the perfusate. Wet weight of the heart was determined at the conclusion of each experiment after trimming the great vessels of fat and bl ot drying with nine-layer cotton gauze. Procedures followed were in accordance with institutional and $\mathrm{N}$ ational I nstitutes of Health guidelines for care and use of animals.

Lactate, $\mathrm{CO}_{2}$, and $\mathrm{pH}$ measurements. The first $1.5 \mathrm{ml}$ of coronary effluent was collected at reflow (see Experimental protocols). Lactate concentration was measured with a GM7 Analyser (Analox micro-Stat, London, UK). The concentrations of $\mathrm{O}_{2}$ and $\mathrm{CO}_{2}$ were measured with a Radiometer (ABL 3, Copenhagen, Denmark). Difference in $\mathrm{CO}_{2}$ content $\left(\mathrm{dCO}_{2} \mathrm{CT}\right)$ between the coronary outflow and inflow was calculated as $\mathrm{dCO}_{2} \mathrm{CT}=\left(\mathrm{Pv}_{\mathrm{CO}_{2}}-\mathrm{Pa}_{\mathrm{CO}_{2}}\right) \times \mathrm{cNm}$, where $\left(\mathrm{Pv}_{\mathrm{CO}_{2}}-\mathrm{Pa}_{\mathrm{CO}_{2}}\right)$ is the difference in $\mathrm{PCO}_{2}(\mathrm{mmHg})$ between coronary effluent and perfusate, $\mathrm{C}$ is the solubility coefficient of $\mathrm{CO}_{2}$ in perfusate at $37^{\circ} \mathrm{C}\left(0.53 \mathrm{ml} \mathrm{CO} 2 \cdot \mathrm{atm}^{-1} \cdot \mathrm{ml}\right.$ perfusate $\left.{ }^{-1}\right)$, and $\mathrm{Vm}$ is molar volume $\left(\left.22.4 \mathrm{ml} \cdot \mathrm{mmol}^{-1} \cdot\right|^{-1}\right)$ (9). Intramural $\mathrm{pH}$ was monitored using a Khuri regional tissue $\mathrm{pH}$ monitor as previously described (10).

ATP and metabolites. To observe changes in tissue nucleotides (ATP, ADP, AMP, IMP) and nucleosides (adenosine, inosine, hypoxanthine, and xanthine), hearts were rapidly frozen in liquid $\mathrm{N}_{2}$ and then lyophilized for $48 \mathrm{~h}$ at $-40^{\circ} \mathrm{C}$ and under 200-Torr vacuum. An aliquot (10 mg) of the dried tissue was homogenized with $800 \mu \mathrm{l}$ of $0.73 \mathrm{M}$ trichloroacetic acid. After centrifugation $(7,000 \mathrm{rpm}, 2 \mathrm{~min})$ at $4^{\circ} \mathrm{C}$, the supernatant $(400 \mu \mathrm{l})$ was removed and added to a new $\mathrm{E}$ ppendorf tube containing an equal volume of tri-n-octylamine and Freon $(1: 1, \mathrm{vol} / \mathrm{vol})$. The sample mixture was then vortexed and centrifuged as before. The aqueous phase was analyzed with HPLC. The mobile phase was prepared as follows: buffer A consisted of $1.47 \mathrm{mM}$ tetrabutylammonium phosphate (TBAP) as a pairing ion and $73.5 \mathrm{M}$ potassium dihydrogen phosphate (PDP), and $0.0 \%$ acetonitrile; buffer B consisted of $10 \%$ acetonitrile in distilled, deionized water, $1.33 \mathrm{mM}$ TBAP, and 66 M PDP. The final concentration of acetonitrile was adjusted by a two-pump control method for achieving optimum peak resolution and separation of nucleotides (3\%) and nucleosides $(0.5 \%)$ at $\mathrm{pH} 3.05$. Standard curves were generated from serial dilutions of ATP, ADP, AMP, I MP, adenosine, hypoxanthine, xanthine, and inosine (Sigma, St. Louis, MO) at $10,25,50,100$, and $500 \mu \mathrm{mol} / \mathrm{l}$. A Water 484 ultraviolet absorbance detector was used for nucleotide and nucleoside determinations. Peak areas from samples were integrated, and least square curves were plotted (2).

RNA isolation. After removal of excess fat and connective tissues, the left ventricular wall was briefly blotted on gauze and frozen in liquid nitrogen and then stored at $-80^{\circ} \mathrm{C}$. An aliquot $(200 \mathrm{mg})$ of the frozen tissue was pulverized and homogenized, and total RNA was extracted with an RNA I solation Kit (Ambion, Austin, TX). RNA samples were tested by ultraviolet absorption at $\mathrm{A}_{260} \mathrm{nM}$ to determine the concentration. The quality and concentration of the RNA samples were further confirmed by electrophoresis on denatured $1 \%$ agarose gels.

Northern bl ot analysis. F or N orthern blot analysis, $15 \mu \mathrm{g}$ of RNA were denatured and electrophoresed in a $1 \%$ formaldehyde agarose gel, transferred to a nitrocellulose transfer membrane (Micron Separations, Westboro, MA), and crosslinked to the membrane with short-wave ultraviolet cross linker. The prehybridizing and hybridizing solutions contained $50 \%$ formamide, $1 \times$ Denhardt's solution, $6 \times$ SSPE, and $1 \%$ SDS. CDNA probes were labeled with [32P]dCTP by random primer extension (PRIME-IT II, Stratagene, LaJ olla, CA) and added to the hybridizing solution at $1 \times 10^{6} \mathrm{cpm} / \mathrm{ml}$. $\mathrm{H}$ ybridization was carried out at $42^{\circ} \mathrm{C}$ for $18 \mathrm{~h}$. The bl ots were then washed several times with a final wash in $1 \times$ standard sodium citrate and $0.1 \% \mathrm{SDS}$ at $65^{\circ} \mathrm{C}$. The relative amount of mRNAs was evaluated using a Phosphorl mager (model 400S, Molecular Dynamics, Sunnyvale, CA). The same size area at each band was taken to measure the intensity, and the same size area at the closest upstream position of each band was taken as the background of the image, respectively (12). The blots were exposed on Kodak X-omat film (Eastman Kodak, Rochester, NY) at $-70^{\circ} \mathrm{C}$. RNA loading was normalized by comparison to that of $28 \mathrm{~s}$ ribosomal RNA. ANT 1 mRNA levels were detected using a 1.4-kb cDNA fragment cloned from the human skeletal muscle (ATCC, Rockville, MD) (19). $\beta-F_{1-}$ ATPase mRNA levels were detected using a 1.8-kb CDNA fragment cloned from human HeLa cell line (ATCC) (3). HSP 70- 1 mRNA levels were detected using a 1.7-kb cDNA fragment cloned from human hippocampus (ATCC) (7). To compare different mRNA levels in the same myocardial sample, aliquots of $15 \mu \mathrm{g}$ total RNA from the myocardium were analyzed by means of sequentially reprobing the membranes with 28s, ANT $_{1}, \mathrm{HSP}_{0}-1$, and $\beta-\mathrm{F}_{1}$-ATPase CDNA probes.

Experimental protocols. Thehypothermia-adaptation protocol was previously described (10). After heart isolation and preparation, a left ventricular balloon volume was defined that would provide a developed pressure between 100 and 140 $\mathrm{mmHg}$. This volume was maintained throughout the protocol. Hearts were excluded from statistical analyses if this volume produced EDPs $>10 \mathrm{mmHg}$. Data were obtained in all hearts ( $n=91$ ) during a 30-min baseline period. The hearts were stabilized at $37^{\circ} \mathrm{C}$ by circulating water at this temperature through the water bath. Hypothermia was induced by decreasing PSS and organ bath temperature to $31^{\circ} \mathrm{C}$ over $20 \mathrm{~min}$. To avoid traumatic insertion of needle-mounted temperature probes, myocardial temperature was not measured in individual hearts. Experimental temperatures were assumed from previously published data obtained in parallel experiments using identical protocols. These describe a fairly linear temperature decrease, from $37^{\circ} \mathrm{C}$ to $31^{\circ} \mathrm{C}$ over the 20 -min time period (10). The pulmonary outflow temperature was monitored continuously with a thermal probe adjusted to the infused temperature. The PSS infusion was stopped, and 60 $\mathrm{ml}$ of oxygenated St. Thomas cardioplegic solution at $4^{\circ} \mathrm{C}$ was injected into the aorta at a rate of $1 \mathrm{ml} / \mathrm{s}$ to begin a 2-h ischemic period. Fifteen milliliters of St. Thomas cardioplegic solution $\left(4^{\circ} \mathrm{C}\right.$ ) containing (in $\left.\mathrm{mmol} / \mathrm{l}\right) 109 \mathrm{NaCl}, 25 \mathrm{~K} \mathrm{Cl}, 21.9$ $\mathrm{NaHCO}_{3}, 16.0 \mathrm{MgCl}_{2}$, and $0.8 \mathrm{CaCl}_{2}$ was injected every 30 min. After the 2-h ischemic period, the hearts were reperfused with oxygenated PSS at $37^{\circ} \mathrm{C}$, and the water bath temperature was increased to $37^{\circ} \mathrm{C}$. Data were recorded for an additional 45 min during reperfusion.

The protocol was altered to provide four different experimental groups: hypothermic adapted $(\mathrm{H})$, hypothermic adapted with glucose provided in cardioplegia (HG), control (C), and glucose provided in cardioplegia (G). In group $\mathrm{H}$, the 
protocol was followed as described above. Mannitol (22 mmol/l) was included as an osmotic control. In group HG, glucose (22 $\mathrm{mmol} / \mathrm{l}$ ) replaced the mannitol (HG). In group $\mathrm{C}$, heart temperature was maintained at $37^{\circ} \mathrm{C}$ over $20 \mathrm{~min}$ instead of being subjected to the hypothermic adaptation protocol; mannitol was provided in cardioplegia. The fourth group, G, underwent the same protocol as control hearts, but glucose replaced mannitol as described for HG.

Some hearts were quickly frozen in liquid nitrogen for measurement of metabolites related to energy use at $50 \mathrm{~min}$ of baseline or $15 \mathrm{~min}$ of reperfusion (Table 2). Samples for RNA measurement were obtained at $45 \mathrm{~min}$ of reperfusion in each group.

Statistical analyses. The reported values are means $\pm \mathrm{SE}$ in the text, Tables 1 and 2, and Figs. 1-4. The Statview 4.5 (FPV) Program (Abacus Concepts, Berkeley, CA, 1995) was used for statistical analyses. Data were evaluated with repeated-measures ANOVA within groups and single factor ANOVA across groups. When significant $F$ values were obtained, individual group means were tested for differences using unpaired t-test. The criterion for significance was $\mathrm{P}<$ 0.05 for all comparisons.

\section{RESULTS}

Functional recovery during reperfusion. The heart weight and left ventricular balloon volume weresimilar in the $C(6.35 \pm 0.39 \mathrm{~g}$ and $1.54 \pm 0.056 \mathrm{ml}$, respectively), $\mathrm{H}(6.26 \pm 0.15 \mathrm{~g}$ and $1.57 \pm 0.073 \mathrm{ml}$, respectively), G (6.33 $\pm 0.21 \mathrm{~g}$ and $1.69 \pm 0.074 \mathrm{ml}$, respectively) and $\mathrm{HG}(6.30 \pm 0.30 \mathrm{~g}$ and $1.67 \pm 0.045 \mathrm{ml}$, respectively). Under the basel ine conditions, there were no significant differences among the groups in EDP, DP, $\mathrm{dP} / \mathrm{dt}_{\text {max }}, \mathrm{HR}, \mathrm{PRP}, \mathrm{CF}, \mathrm{MVO}_{2}$ and $\mathrm{O}_{2}$ Ext. Hemodynamic results are summarized in Table 1 . Twenty minutes of hypothermia decreased cardiac function, but nosignificant changes occurred in the control group (Table 1) during 20 min perfusion at $37^{\circ} \mathrm{C}$.

In Table 1 and $\mathrm{Fig.} \mathrm{1,} \mathrm{the} \mathrm{data} \mathrm{demonstrate} \mathrm{that} \mathrm{the}$ addition of glucose to cardioplegic solution in the hypothermia-adapted hearts (HG) provided superior functional recovery compared with that observed in other groups. Both the $\mathrm{H}$ and the $\mathrm{G}$ groups showed a better functional recovery than the $\mathrm{C}$ group. The HG group hearts demonstrated higher developed pressure and rate-pressure products than either $\mathrm{H}$ or $\mathrm{G}$. This implies that these modes provide a synergistic functional response during reperfusion.

I schemic contracture As noted in METHODS, a specific balloon volume was adjusted and then maintained throughout the protocol, allowing comparisons of LVP under constant end-diastolic volume. After injecting cardioplegic solution, the LVP was always near 0 $\mathrm{mmHg}$. The beginning of ischemic contracture was defined by the initial rise in LVP $>2 \mathrm{mmHg}$. Ischemic contracture started significantly later in hypothermiaadapted hearts (95.4 $\pm 4.2 \mathrm{~min}$ ) than in control hearts (63.9 $\pm 3.2 \mathrm{~min})$. However, no ischemic contracture was observed in 120 min of ischemia in $\mathrm{G}$ and HG.

Accumulation of catabolic products. An obvious increase in accumulation of lactate and $\mathrm{CO}_{2}$ was noted in $\mathrm{G}$ at $120 \mathrm{~min}$ of ischemia. Lactate accumulation in the $\mathrm{G}$ and $\mathrm{HG}$ groups was significantly greater than in $\mathrm{C}$ and $\mathrm{H}$. Accumulation of both metabolites was signifi- cantly greater in HG than $\mathrm{H}$. Additionally, myocardial $\mathrm{pH}$ was significantly lower in $\mathrm{G}$ and $\mathrm{HG}$ than $\mathrm{C}$ and $\mathrm{H}$. The $\mathrm{pH}$ was lower in $\mathrm{HG}$ than $\mathrm{H}$. Figure 2 summarizes the results. These data imply that anaerobic metabolism is increased with glucose provision to cardioplegia in both control and hypothermic-adapted hearts.

ATP and metabolites. Table 2 summarizes data relevant to ATP and its principal metabolites during reperfusion. Significant ATP depletion occurred in all groups. However, ATP, ADP, and TNN concentrations were higher in $\mathrm{HG}, \mathrm{H}$, and $\mathrm{G}$ than in $\mathrm{C}$. Glucose provision to hypothermic-adapted hearts augmented ATP concentrations; ATP in $\mathrm{HG}$ was greater than in $\mathrm{H}$.

$\beta-\mathrm{F}_{1}$-ATPase, $\mathrm{ANT}_{1}$ and HSP 70-1 mR NAs. Hybridization of the mRNA probes for $\beta-F_{1}$-ATPase, $A N T_{1}$, and HSP 70- 1 is illustrated in Fig. 3. Across individual membranes, there were no significant differences in 28s band intensities. Steady-state mRNA levels for ANT ${ }_{1}$, $\beta-F_{1}$-ATPase, and HSP70-1 were normalized to $28 \mathrm{~s}$ ribosomal RNA intensity, and each group's average values were normalized to C (Fig. 4). The mRNA levels for the three genes are about threefold higher in $\mathrm{H}$ and HG than in $\mathrm{C}$, but there are no noticeable differences between $C$ and $G$. Furthermore, no significant differences occur between $\mathrm{H}$ and $\mathrm{HG}$. These data imply that glucose does not alter expression of these genes in either control or hypothermic-adapted hearts.

\section{DISCUSSION}

This study examined functional and metabolic parameters during ischemia and reperfusion, which might be altered by glucose provision to cardioplegic-arrested hearts after hypothermic adaptation. Myocardial ATP concentration provided an index for high-energy phosphate reserves in this perfused heart model. Although maintenance of ATP closely parallels preservation of cardiac function after reperfusion in isolated rabbit hearts (10), ATP represents only a portion of the high-energy phosphate reserve available to the heart. Phosphocreatine serves as the principal energy reservoir but is rapidly depleted during the first few minutes of ischemia $(14,15)$. Exponential slowing of phosphocreatine depletion with more prolonged ischemia reflects induction of anaerobicATP production through lactateand proton-generating glycolytic pathways (14). Lactate production occurs despite metabolic slowing and glycolytic inhibition caused by hypothermia or hypothermic adaptation $(10,11,14)$. Anaerobic ATP production can maintain cytosolic ATP levels until more prolonged ischemia depletes cardiac glycogen stores. Although phosphocreatine is rapidly restored, ATP depletion persists after reperfusion or reoxygenation $(16,20)$. This persistence is generally attributed to purine loss and degradation. Thus, although phosphocreatine repletion rate provides an index of mitochondrial function during reperfusion, the postischemic ATP concentration reflects the status of the high-energy phosphate reserve at the end of a prolonged ischemic period.

Glucose supplied in cardioplegia solution can slow ischemic ATP depletion at various temperatures and metabolic rates $(9,13)$. Presumably this ATP preserva- 
Table 1. Hemodynamics

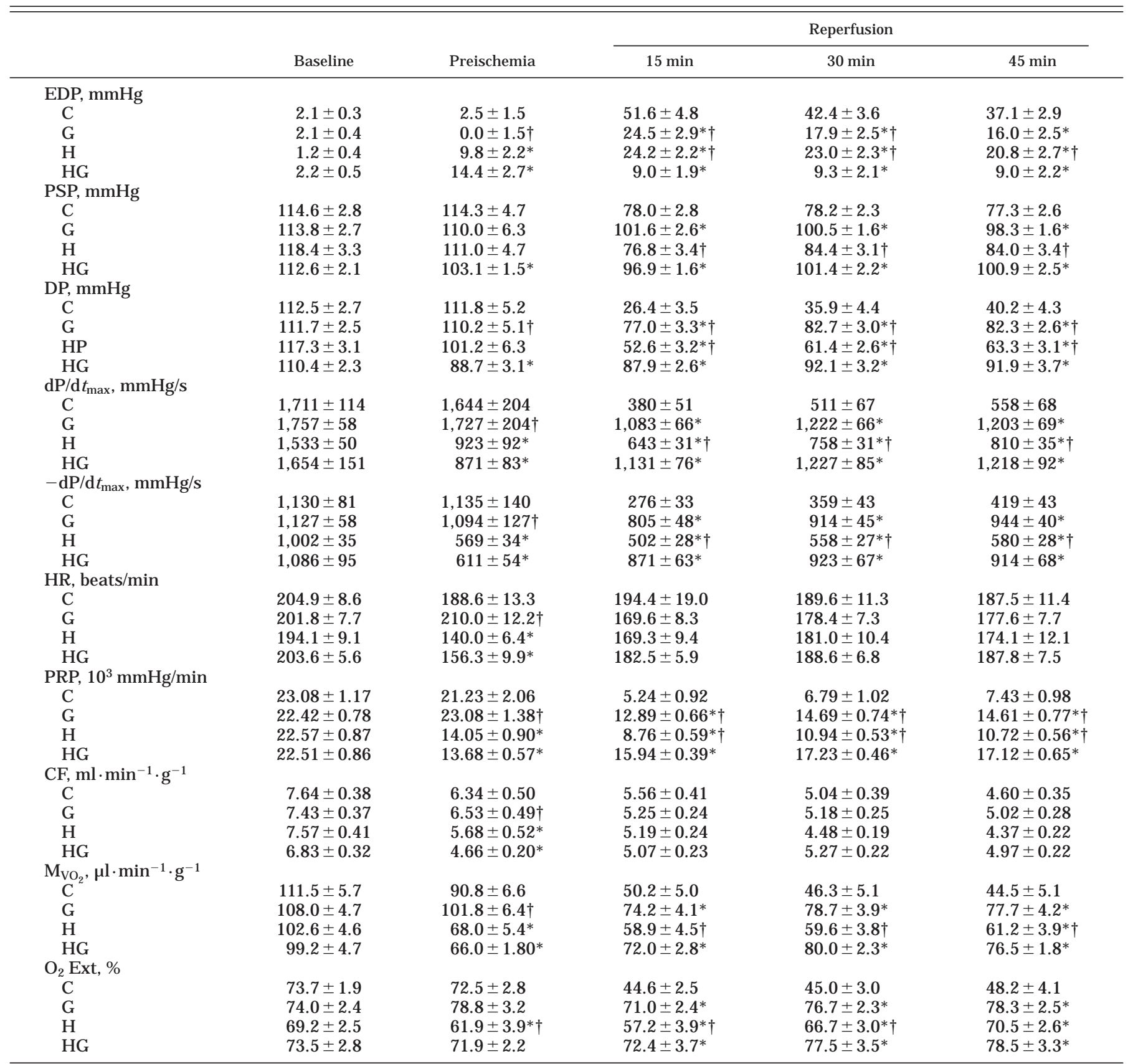

Values are means \pm SE. Hemodynamic indexes were determined in isolated reperfused hearts at baseline; 20 min of preischemic perfusion at $31^{\circ} \mathrm{C}$ or $37^{\circ} \mathrm{C}$; and 15,30 , and $45 \mathrm{~min}$ of reperfusion as described in METHODS. C, control group $(n=16) ; G$, glucose group $(n=16) ; H$, hypothermia adapted $(n=12) ; H G$, hypothermia adapted and glucose $(n=10) ; C F$, coronary flow; DP, devel oped pressure; $d P / d t_{\text {max }}$, maximum of positive or negative first derivative of left ventricular pressure; EDP, end diastolic pressure; HR, heart rate; PRP, product of HR and DP; $\mathrm{PSP}$, peak of left ventricular pressure; $\mathrm{M}_{\mathrm{VO}_{2}}$, myocardial oxygen consumption; $\mathrm{O}_{2} \mathrm{Ext}$, oxygen extraction. *P $<0.05$ compared with $\mathrm{C}$; †P $<$ 0.05 compared with HG.

tion occurs through enhanced transarcolemmal glucose transport, which promotes anaerobic ATP production by glycolytic pathways. The increased lactate and $\mathrm{H}^{+}$ ion production induced by glucose provision during ischemia in the current study supports this contention. Hypothermic adaptation decreases both ATP use and production rates (10). Preservation of ATP during subsequent warm ischemia occurs because ATP use is reduced to a greater extent than is ATP production.
Thus, relative to the first hypothesis stated in the introduction, glucose provision modestly accelerates anaerobic lactate and ATP production despitethe metabolic downregulation induced by preceding hypothermia. Net increased preservation of ATP results. The glucose provision also further augments systolic and diastolic functional parameters after ischemia in hypothermic-adapted hearts. The level of postischemic cardiac function has been closely related to the level of 


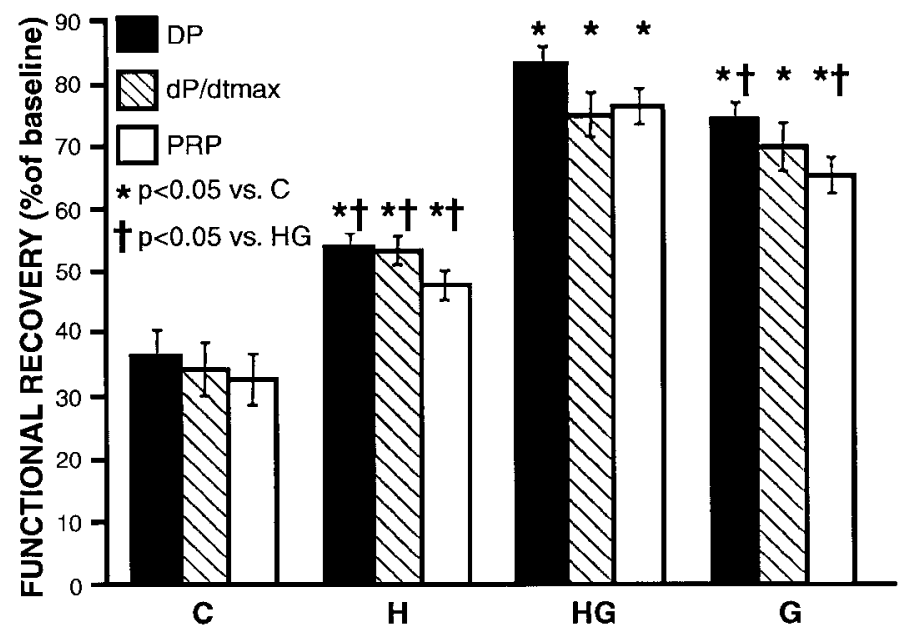

Fig. 1. Functional recovery during reperfusion. $\mathrm{C}$, control group; $\mathrm{H}$, hypothermia adapted; G, glucose provided in cardioplegia; HG, hypothermic adaptation and glucose in cardioplegia; DP, developed pressure; $\mathrm{dP} / \mathrm{dt}_{\max }$, positive maximum of first derivative of left ventricular pressure; PRP, product of $H R$ and DP.

\section{ATP preservation in this perfused rabbit heart model} $(10,11)$.

The second proposed hypothesis states that signaling for the heat shock response and mitochondrial biogenesis is linked to the specific metabolites ATP and lactate. Hypothermic adaptation accentuates and pre serves these responses after reperfusion. This occurs in association with elevated ATP and reduced lactate levels during ischemia. Several studies have linked concentrations of one or the other of these metabolites with the intensity of the HSP signal elucidated $(4,8)$. Provision of glucose in cardioplegia with concomitant alterations in these metabolite levels affords an opportunity to study these relationships in an intact heart model using a signal promoter other than heat shock or hypoxia before oxidative stress. Some evidence exists that a metabolic or hypoxic stress leading to ATP depletion activates heat shock factor, promotes transcription of HSP gene, and results in an el evation in the gene's message $(1,8)$. However, the primary contention that ATP depletion solely promotes the HSP response conflicts with findings from our experiments in hypothermic adaptation, which demonstrate that HSP mRNA levels are el evated in association with increased ATP preservation.

Glucose reduces ATP depletion and promotes lactate production during near total ischemia but does not alter the intensity of the HSP response in this perfused rabbit heart model. Myrmel and coauthors (8) suggested that anaerobic metabolism provides a strong stimulus for HSP 70 transcription. However, they based this suggestion on conflicting data, which were obtained in a perfused rat heart model during low-flow or total ischemia. Close scrutiny of these data reveals that these investigators could not demonstrate a correlation between lactate production and HSP70 mRNA expression (8). HSP70 mRNA levels were most elevated instead at the lowest coronary flow rate, which preserved systolic and diastolic function, yet did not opti- mize lactate production. F urthermore, although replacement of glucose with 2-3-deoxyglucose reduced both lactate production and HSP mRNA expression during low-flow ischemia, no comparable changein HSP expression occurred during total ischemia despite pronounced inhibition of lactate production. Our own data conform to this apparent disassociation of lactate production and HSP expression during severe ischemia. No enhancement in HSP mRNA expression occurred when glucose added to perfusate increased lactate and $\mathrm{H}^{+}$ production in the isolated rabbit hearts either with or without hypothermic adaptation. Studies of HSP70 expression in cultured neonatal cardiomyocytes have shown that, although metabolic inhibition of ATP production does enhance HSP expression, HSP70 induction precedes and remains unmodified by ATP deple-
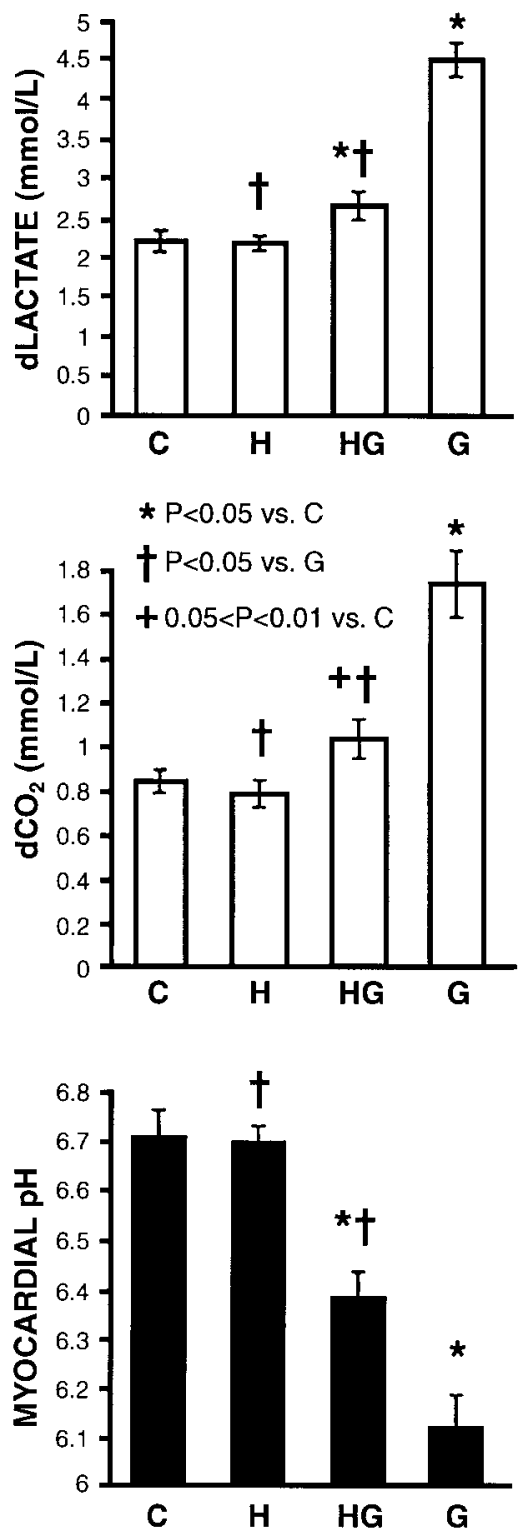

Fig. 2. Accumulation of catabolic products during 120-min ischemia. Differences in lactate concentration (dLactate), $\mathrm{CO}_{2}$ concentration $\left(\mathrm{dCO}_{2}\right)$, between coronary effluent, and inflow perfusates $(\mathrm{n}=24 \mathrm{in}$ $\mathrm{C}, \mathrm{n}=18$ in $\mathrm{H}, \mathrm{n}=17$ in $\mathrm{G}$, and $\mathrm{n}=12$ in $\mathrm{HG}$ ). 
Table 2. ATP and metabolites

\begin{tabular}{cccccc}
\hline \hline & $\mathrm{B}(\mathrm{n}=6)$ & $\mathrm{C}(\mathrm{n}=9)$ & $\mathrm{G}(\mathrm{n}=9)$ & $\mathrm{H}(\mathrm{n}=5)$ & $\mathrm{HG}(\mathrm{n}=6)$ \\
\hline ATP & $20.60 \pm 0.83^{*}+$ & $1.85 \pm 0.33$ & $10.12 \pm 0.23^{*}+$ & $12.25 \pm 1.09 * \dagger$ & $15.24 \pm 0.87^{*}$ \\
ADP & $4.53 \pm 0.46^{*}$ & $2.58 \pm 0.85$ & $4.17 \pm 0.15^{*}$ & $4.02 \pm 0.50^{*}$ & $3.91 \pm 0.30^{*}$ \\
TNN & $25.48 \pm 1.12^{*}$ & $5.18 \pm 0.29$ & $14.65 \pm 0.35^{*}$ & $16.63 \pm 1.48^{*}$ & $19,50 \pm 1.09 *$ \\
TDN & $0.53 \pm 0.06$ & $1.38 \pm 0.31$ & $0.56 \pm 0.07$ & $0.79 \pm 0.23$ & $0.71 \pm 0.12$ \\
\hline
\end{tabular}

Values are means \pm SE in $\mu \mathrm{mol} / \mathrm{g}$ dry tissue. TNN, total nondiffusible nucleotides; TDN, total diffusible nucleosides; $\mathrm{C}$, control group at 15 min reperfusion; $\mathrm{G}$, glucose group at 15 min reperfusion; $\mathrm{H}$, hypothermia-adapted group at 15 min reperfusion; $\mathrm{HG}$, hypothermia-adapted with glucose group at 15 min reperfusion; $B$, baseline condition. $* P<0.05$ vs. $C ; \uparrow P<0.05$ vs. HG.

tion caused by hypoxia (4). These findings would imply that other factors can modify induction of HSP mRNA expression by anaerobic glycolysis products. Thus, in concordance with cultured cardiomyoctye studies, neither ATP depletion nor lactate production appear to be principal regulators of HSP70 mRNA in the current model.

Coordinated preservation of HSP responseand signaling for mitochondrial biogenesis is a characteristic of hypothermic adaptation in this perfused rabbit heart model (10). Similar coordination occurs in hibernating or cold-adapted tissues subjected to cold stress. The mechanisms responsible for this coordination have not been studied, although injury reduction and enhanced ATP preservation appear to be necessary for maintenance of steady-state mRNA levels for these mitochondrial proteins after ischemia $(10,12)$. Thus we postulated that ATP availability might play a role in determining these signal levels. However, glucose augmentation of postischemic ATP concentration does not further enhance the signal level. This implies that ATP levels do not directly correlate with the message intensity. Conceivably, preservation of thesenuclear encoded messages requires only a minimum cytosolic ATP concentration. However, the true pathways that coordinate signal preservation have not been identified.

The significance of steady-state level mRNA expression for these genes remains speculative. We do not
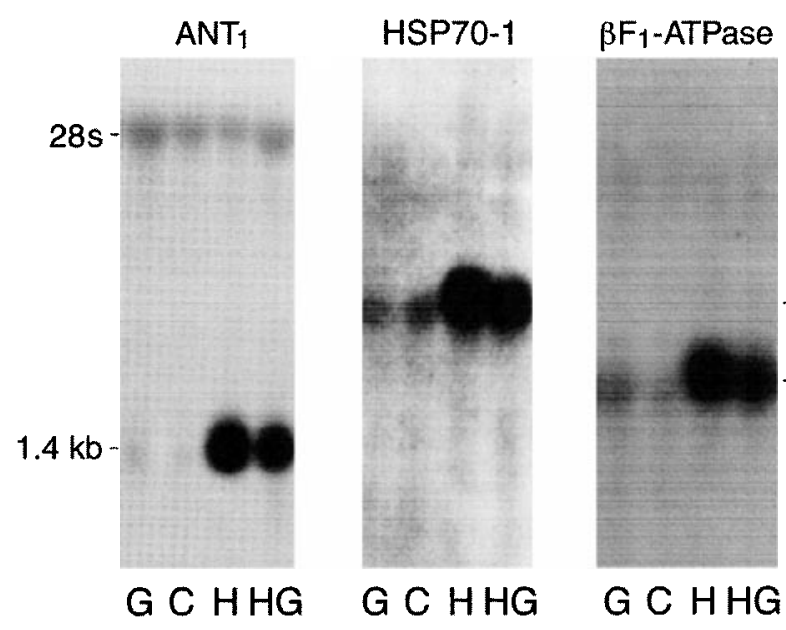

$-2.8 k b$

$-2.1 \mathrm{~kb}$

Fig. 3. A representative Northern blot. Each lane was loaded with 15 $\mu \mathrm{g}$ total RNA from ventricular myocardium and sequentially re probed for $28 \mathrm{~s}$, adenine nucleotide translocator $\left(\mathrm{ANT}_{1}\right)$, heat shock protein 70- 1 (HSP70-1), and $\beta-F_{1}$-ATPase. Samples were taken C, $\mathrm{G}, \mathrm{HG}$, and $\mathrm{H}$ hearts 45 min after starting reperfusion. Intensities in $\mathrm{H}$ and $\mathrm{HG}$ lanes for all 3 RNAs are greater. suggest that this signal preservation plays a role in elevation of postischemic ATP levels. Mitochondrial damage and dysfunction does contribute to myocardial damage during ischemia and reperfusion $(16,17,21)$. Loss of adenine nucleotide translocator and mitochondrial ATPaseactivity correlates with postischemic mitochondrial dysfunction. Thus restoration of mitochondrial function after ischemic injury would logically require resynthesis and/or reconfiguration of these major mitochondrial membrane components. Previously documented close coordination between adenine nucleotide translocator protein and gene expression predicts that eventual protein resynthesis after ischemia requires preserved gene expression(18).

\section{Perspectives}

In summary, both hypothermic adaptation and glucose provision in cardioplegia separately improve cardiac function and ATP preservation after reperfusion. The combination of these factors provides superior myocardial protection. Hypothermic adaptation both with or without glucose provision accentuates HSP gene expression and maintains signaling for synthesis of mitochondrial membrane proteins. Induction of the HSP response with its associated myocardial protection

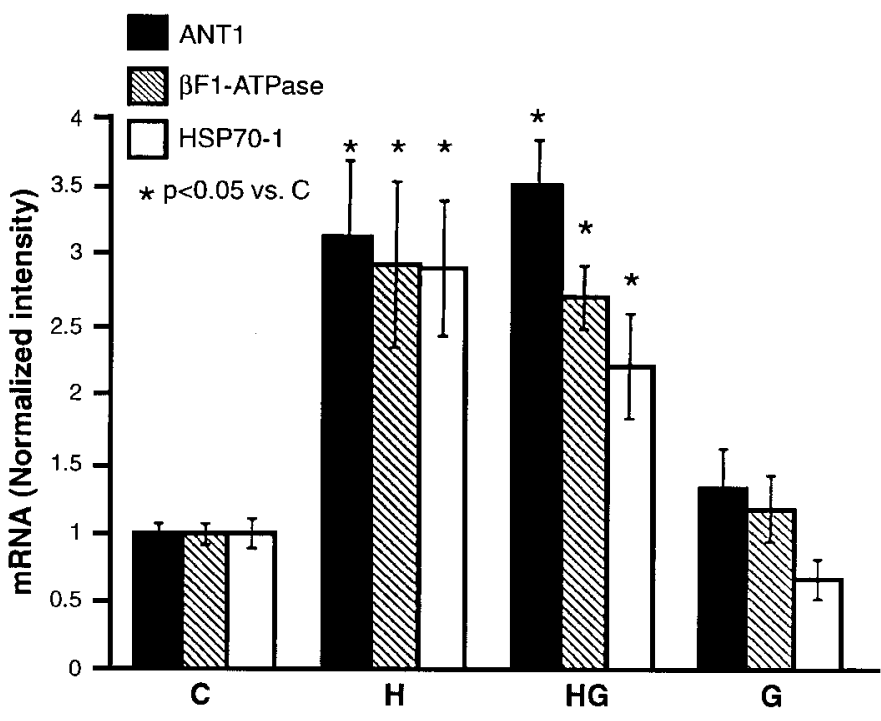

Fig. 4. Steady-state mRNA levels. All transcript levels are relative to $28 \mathrm{~s}$ band intensity and normalized to $\mathrm{C}$. Steady-state RNA levels of nucl ear encoded genes for $\mathrm{ANT}_{1}, \beta-\mathrm{F}_{1}-\mathrm{ATP}$ ase subunit, and HSP 70- 1 are greater in $\mathrm{H}(\mathrm{n}=4)$ and $\mathrm{HG}(\mathrm{n}=4)$ than those in $\mathrm{C}(\mathrm{n}=8)$ and $\mathrm{G}$ $(n=6)$. mRNA levels are not significantly different when comparing C vs. G. 
has received particular attention in the clinical literature. I nvestigators have proposed using various stressors such as heat, ischemia, or hypoxia before cardiac surgery $(6,8)$. However, the present data indicate that these extreme measures are not necessary. Hypothermia, an agent now routinely used during cardiac surgery, induces the HSP response. Glucose added to cardioplegia further optimizes the functional response to hypothermic adaptation. The importance of other stress agents before cardiac surgery should be considered only if they enhance the effects of this routine method.

This work was funded in part by National Heart, Lung, and Blood Institute Grants HL-47805 and HL-60666- 1 and a grant from Children's Hospital Research Endowment Fund.

We thank Drs. Shi-han Chen, Yue Yao, and Linghen Li for advice and counsel.

Address for reprint requests and other correspondence: $M$. A. Portman, Division of Cardiology, Children's Hospital and Regional Medical Center (CH-11), 4800 Sand Point Way NE, Seattle, WA 98105 (E-mail: mportm@chmc.org).

Received 15 October 1998; accepted in final form 5 March 1999.

\section{REFERENCES}

1. Benjamin, I. V., S. Horte, M. L. Greenberg, R. J . Alpern, and R. S. Williams. Molecular signals for activation of heat shock transcription factor during ischemia. J. Clin. Invest. 89: 16851689, 1992.

2. Childs, K. F., X. H. Ning, and S. F. Bolling. Simultaneous detection of nucleotides, nucleosides and oxidative metabolites in myocardial biopsies. J . Chromatogr. B Biomed. Appl. 678: 181186, 1996.

3. Garboczi, D. N., A. H. Fox, S. L. Gerring, and P. L. Pediersen. $\beta$ Subunit of rat liver mitochondrial ATP synthase: CDNA cloning, amino acid sequence, expression in Eschericia coli, and structural relationship to adenylate kinase. Biochemistry 27: 553560,1988

4. Iwaki, K., S. H. Chi, W. H. Dillmann, and R. Mestril. Induction of HSP70 in cultured rat neonatal cardiomyocytes by hypoxia and metabolic stress. Circulation 87: 2023-2032, 1993.

5. Klingenspor, M., M. Ivemeyer, H. Wiesinger, K. Haas, G. Heldmaier, and R. J. Wiesner. Biogenesis of thermogenic mitochondria in brown adipose tissue of Djungarian hamsters during cold adaptation. Biochem. J . 316: 607-613, 1996.

6. Knowlton, A. Heat-shock proteins, stress, and the heart. Ann. NY Acad. Sci. 723: 128-137, 1994

7. McCully, J . D., T. Myrmel, M. M. Lotz, I. B. Krukenkamp, and S. Levitsky. The rapid expression of myocardial hsp 70 mRNA and the heat shock $70 \mathrm{kDa}$ protein can be achieved after only a brief period of retrograde hyperthermic perfusion. J . Mol. Cell. Cardiol. 27: 873-882, 1995.
8. Myrmel, T., J . D. McCully, L. Malikin, I. B. Krukenkamp, and S. Levitsky. Heat-shock protein 70 mRNA is induced by anaerobic metabolism in rat hearts. Circulation 90: II299-305, 1994.

9. Ning, X. H., K. F. Childs, and S. F. Bolling. Glucose level and myocardial recovery after warm arrest. Ann. Thorac. Surg. 62: 1825-1829, 1996.

10. Ning, X.-H., C.-S. Xu, Y. Song, Y. Xiao, Y.-J . Hu, F. Lupinetti, and M. Portman. Hypothermia preserves function and signaling for mitochondrial biogenesis during subsequent ischemia. Am. J . Physiol. 274 (Heart Circ. Physiol. 43): H786-H793, 1998.

11. Ning, X.-H., C.-S. Xu, Y. C. Song, K. F. Childs, Y. Xiao, S. F. Bolling, F. M. Lupinetti, and M. A. Portman. Temperature threshold and modulation of energy metabolism in the cardioplegic arrested heart. Cryobiology 36: 2-11, 1998.

12. Ning, X.-H., C.-S. Xu, Y. C. Song, Y. Xiao, Y.-J . Hu, F. M. Lupinetti, and M. A. Portman. Temperature threshold and preservation of signaling for mitochondrial membrane proteins during ischemia in rabbit heart. Cryobiology 36: 321-329, 1998.

13. Owen, P., E. F. D. Toit, and L. H. Opie. The optimal glucose concentration for intermittent cardioplegia in isolated rat heart when added to St. Thomas' Hospital cardioplegic solution. J . Thorac. Cardiovasc. Surg. 105: 995-1006, 1993.

14. Portman, M. A., and G. E. Eyster. Myocardial buffering capacity and high energy phosphate utilization during hypothermic circulatory arrest and recovery in the newborn lamb in vivo. J . Thorac. Cardiovasc. Surg. 108: 946-952, 1995

15. Portman, M. A., A. L. Panos, Y. Xiao, D. L. Anderson, G. M. Alfieris, X.-H. Ning, and F. M. Lupinetti. I nfluence of cardioplegia $\mathrm{pH}$ on cellular energy metabolism and $\mathrm{H}^{+}$ion flux during neonatal hypothermic circulatory arrest and reperfusion. J. Thorac. Cardiovasc. Surg. 114: 601-608, 1997.

16. Portman, M.A., T. A. Standaert, and X.-H. Ning. The relation of myocardial oxygen consumption and function to high energy phosphate utilization during graded hypoxia and reoxygenation in sheep in vivo. J . Clin. Invest. 95: 2134-2132, 1995.

17. Portman, M.A., T.A. Standaert, and X. H. Ning. Developmental changes in ATP utilization during graded hypoxia and reoxygenation in the heart in vivo. Am. J . Physiol. 270 (Heart Circ. Physiol. 39): H216-H223, 1996.

18. Portman, M. A., Y. Xiao, Y. Song, and X.-H. Ning. Expression of adenine nucleotide translocator parallels maturation of respiratory control in vivo. Am. J. Physiol. 273 (Heart Circ. Physiol. 42): H 1977- H 1983, 1997.

19. Stepien, G., A. Torroni, A. B. Chung, J . A. Hodge, and D. C. Wallace. Differential expression of adenine nucleotidetranslocator isoforms in mammalian tissues and during muscle cel differentiation. J . Biol. Chem. 267: 14592-14597, 1992.

20. Swain, J . L., R. L. Sabina, P. A. McHale, J . C. Greenfield, and E. W. Holmes. Prolonged myocardial nucleotide depletion after brief ischemia in the open-chest dog. Am. J . Physiol. 242 (Heart Circ. Physiol. 11): H818-H826, 1982.

21. Zuurbier, C. J ., and J. H. G. M. V. Beek. Mitochondrial response to heart rate steps in isolated rabbit heart is slowed after myocardial stunning. Circ. Res. 81: 69- 75, 1997. 